\title{
HÆMODYNAMIC EFFECTS OF HISTAMINE IN MITRAL STENOSIS
}

\author{
BY \\ S.-E. LINDELL, B. SÖDERHOLM, AND H. WESTLING \\ From the Department of Clinical Physiology, University of Göteborg, Sweden \\ Received October 22, 1962
}

In the functional evaluation of patients with heart disease, detailed information is sometimes required, and the patient is subjected to a heart catheterization which allows the measurement of flow, intravascular pressure, and other variables. It is generally agreed that these measurements should be made not only with the patient at rest but also during exercise. In addition, it is sometimes desirable to analyse whether pulmonary hypertension is caused by anatomical changes in the pulmonary vessels or by an increased vascular tone (so-called active pulmonary hypertension). To this end vasodilator drugs, notably acetylcholine, have been used. Several workers (for example, Söderholm and Werkö, 1959) have demonstrated that the infusion of acetylcholine to patients with mitral valvular disease often causes a fall in pulmonary arterial pressure and a decrease in the pulmonary vascular resistance.

In the present paper the hæmodynamic effects of histamine, another powerful endogenous vasodilator substance, have been examined.

\section{Methods AND SUBJeCtS}

The heart catheterizations were performed in the morning after a light meal. A double lumen catheter (No. 9) was wedged in a pulmonary artery ("PCV" position) with the proximal lumen in the pulmonary artery. In a few cases another catheter (No. 6) was introduced into the right atrium. Brachial arterial pressure was recorded from an indwelling polythene tube (Bernéus et al., 1954). Pressures were recorded with strain-gauge manometers on a six-channel direct-writing recorder (Mingograph, Elema). A point $5 \mathrm{~cm}$. dorsal to the sternal angle was used as zero reference level. Mean pressures were measured by planimetrical integration. Cardiac output was estimated according to Fick's direct principle. Gas analysis and measurements of oxygen saturation and oxygen capacity were performed as described by Söderholm (1957). Arterial carbon dioxide tension was measured as described by Carlsten and Söderholm (1960). The alveolo-arterial difference in oxygen tension was calculated from the alveolar air equation and the Dill curve (Rahn and Fenn, 1955).

Pressures and flows were studied in the supine position at rest, during exercise on a bicycle ergometer (200 kpm. per min.), and during a continuous intravenous infusion of histamine in a dose that was chosen so as to cause moderate circulatory effects (tachycardia and facial flushing): about $0 \cdot 1-0 \cdot 3 \mu \mathrm{g}$. histamine base per kg. and per minute was given. All measurements were made under steady-state conditions as judged by pulse rate and pressures. After introduction of the catheters the patients were allowed to rest for 30 minutes, and measurements were then made at rest and during exercise. After the exercise 30-45 minutes were allowed to pass before histamine was given. Experience in this laboratory has shown that the hæmodynamic and respiratory values are restored, about 30 minutes after exercise, to those at rest: this was checked in one patient (No. 4). In two other patients in the present study it was found that the arterial $\mathrm{O}_{2}$ saturation had been brought to normal before histamine was given, and in all patients we made 
TABLE I

Details of Eight Patients

\begin{tabular}{|c|c|c|c|c|c|c|c|c|c|c|}
\hline $\begin{array}{l}\text { Patient } \\
\text { and } \\
\text { sex }\end{array}$ & $\begin{array}{l}\text { Age } \\
\text { (yr.) }\end{array}$ & $\begin{array}{c}\text { Height } \\
\text { (cm.) }\end{array}$ & $\begin{array}{c}\text { Weight } \\
\text { (kg.) }\end{array}$ & $\begin{array}{c}\text { Heart } \\
\text { volume } \\
\text { (ml./m.2 } \\
\text { B.S.A.) }\end{array}$ & Rhythm & $\begin{array}{l}\text { Vital } \\
\text { capacity* } \\
(\text { (.) }\end{array}$ & $\underset{(\%)}{\text { FEV }_{1.0} / \mathrm{V} . \mathrm{C} . \dagger}$ & $\begin{array}{c}\text { Clinical } \\
\text { diagnosis }\end{array}$ & $\begin{array}{c}\text { Functional } \\
\text { group } \neq\end{array}$ & Treatment \\
\hline $\begin{array}{ll}1 & F \\
2 & F \\
3 & F \\
4 & F\end{array}$ & $\begin{array}{l}27 \\
35 \\
40 \\
50\end{array}$ & $\begin{array}{l}162 \\
171 \\
169 \\
167\end{array}$ & $\begin{array}{l}54 \\
61 \\
88 \\
61\end{array}$ & $\begin{array}{l}480 \\
360 \\
410 \\
490\end{array}$ & $\begin{array}{l}\text { SR } \\
\text { SR } \\
\text { SR } \\
\text { SR }\end{array}$ & $\begin{array}{l}3 \cdot 31(3 \cdot 58) \\
2 \cdot 87(3 \cdot 73) \\
2 \cdot 92(3 \cdot 57) \\
2 \cdot 22(3 \cdot 24)\end{array}$ & $\begin{array}{l}87(85) \\
89(83) \\
88(82) \\
86(79)\end{array}$ & $\begin{array}{c}\text { MS } \\
\text { MS } \\
\text { MS } \\
\text { MS(+MI?) }\end{array}$ & $\begin{array}{l}\text { II } \\
\text { II } \\
\text { II } \\
\text { III }\end{array}$ & $\begin{array}{l}\text { Digitalis } \\
\text { MS operation } \overline{7} \text { years previously; }\end{array}$ \\
\hline $\begin{array}{l}5 \mathrm{~F} \\
6 \mathrm{M}\end{array}$ & $\begin{array}{l}56 \\
39\end{array}$ & $\begin{array}{l}160 \\
167\end{array}$ & $\begin{array}{l}64 \\
56\end{array}$ & $\begin{array}{l}320 \\
800\end{array}$ & $\begin{array}{l}\text { SR } \\
\text { AF }\end{array}$ & $\begin{array}{l}2 \cdot 97(2 \cdot 82) \\
3 \cdot 44(4 \cdot 43)\end{array}$ & $\begin{array}{l}77(77) \\
81(77)\end{array}$ & $\begin{array}{l}\text { MS } \\
\text { MS }\end{array}$ & II-III & MS operation $\overline{6}$ years previously; \\
\hline $7 \mathrm{~F}$ & 44 & 148 & 52 & 920 & $\mathbf{A F}$ & $-(2 \cdot 70)$ & $-(81)$ & MS & II-III & MS operation 6 years previously; \\
\hline $8 \mathrm{~F}$ & 46 & 161 & 52 & 730 & $\mathbf{A F}$ & $2 \cdot 38(3 \cdot 22)$ & $80(80)$ & MS & III & Digitalis \\
\hline
\end{tabular}

* Predicted normal values are given within parantheses.

+ Forced expiratory volume in 1 sec. as per cent of vital capacity.

$¥$ N.Y. Heart Association.

$\stackrel{+}{\mathbf{H}}=$ sinus rhythm. $\mathbf{A F}=$ atrial fibrillation. $\quad \mathbf{M S}=$ mitral stenosis. $\quad \mathbf{M I}=$ mitral insufficiency.

TABLE II

Hemodynamic OBSERVATIONS

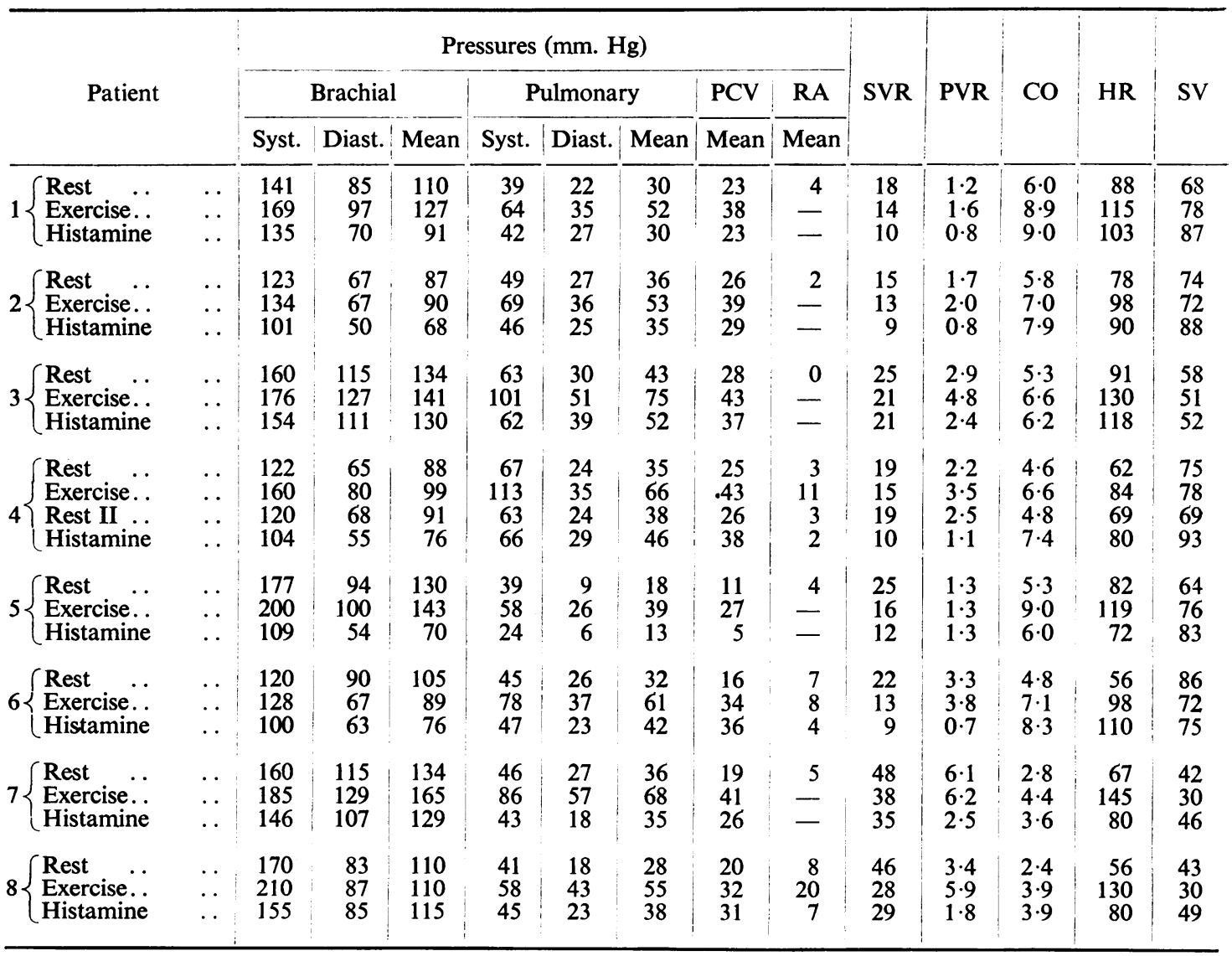

$\mathrm{PCV}=$ Pulmonary artery wedge pressure. $\mathrm{RA}=$ Right atrium pressure.

$\mathrm{SVR}=$ Systemic vascular resistance $\frac{\overline{\mathbf{P}}_{\mathrm{BA}}}{\mathbf{C O}}$
$\mathbf{P V R}=$ Pulmonary vascular resistance $\frac{\overline{\mathbf{P}}_{\mathbf{P A}}-\overline{\mathbf{P}}_{\mathbf{P C V}}}{\mathbf{C O}}$

$\mathrm{CO}=$ Cardiac output (1./min.).

$\mathrm{HR}=$ Heart rate.

$\mathrm{SV}=$ Stroke volume $(\mathrm{ml}$.). 
TABLE III

RESPIRATORY OBSERVATIONS

\begin{tabular}{|c|c|c|c|c|c|c|c|c|c|c|c|}
\hline Patient & $\begin{array}{l}\mathrm{SaO}_{2} \\
(\%)\end{array}$ & $\begin{array}{c}\mathrm{O}_{2} \text {-cap. } \\
\text { (ml./100 ml.) }\end{array}$ & $\begin{array}{c}(\mathrm{A}-\mathrm{v}) \mathrm{O}_{2} \\
(\mathrm{ml} . / \mathrm{l} .)\end{array}$ & $\dot{\mathrm{V}}_{\mathrm{O}_{2}}$ & $\dot{\mathbf{V}}_{\mathbf{E}}$ & $\dot{\mathrm{V}}_{\mathbf{A}}$ & RF & $\mathrm{PaCO}_{2}$ & $\begin{array}{c}(\mathrm{A}-\mathrm{a}) \mathrm{O}_{2} \\
(\mathrm{~mm} . \mathrm{Hg})\end{array}$ & Qs/Qt & $\underset{(\mathrm{mm} . \mathrm{Hg})}{\Delta \mathrm{p}}$ \\
\hline $1\left\{\begin{array}{l}\text { Rest } \\
\text { Exercise } \\
\text { Histamine }\end{array}\right.$ & $\begin{array}{l}97 \cdot 7 \\
95 \cdot 9 \\
93 \cdot 7\end{array}$ & $\begin{array}{l}16 \cdot 7 \\
17 \cdot 1 \\
15 \cdot 9\end{array}$ & $\begin{array}{l}34 \\
71 \\
26\end{array}$ & $\begin{array}{l}205 \\
635 \\
234\end{array}$ & $\begin{array}{r}6 \cdot 5 \\
16 \cdot 8 \\
7.9\end{array}$ & $\begin{array}{r}3.8 \\
11.6 \\
4.4\end{array}$ & $\begin{array}{l}18 \\
27 \\
22\end{array}$ & $\begin{array}{l}39 \\
38 \\
36\end{array}$ & $\begin{array}{l}10 \\
21 \\
32\end{array}$ & $\begin{array}{r}2 \\
12 \\
26\end{array}$ & $\begin{array}{l}5 \\
9 \\
6\end{array}$ \\
\hline $2\left\{\begin{array}{l}\text { Rest } \\
\text { Exercise } \\
\text { Histamine }\end{array}\right.$ & $\begin{array}{l}98 \cdot 0 \\
94 \cdot 5 \\
92 \cdot 5\end{array}$ & $\begin{array}{l}15 \cdot 4 \\
16 \cdot 0 \\
15 \cdot 7\end{array}$ & $\begin{array}{l}40 \\
78 \\
31\end{array}$ & $\begin{array}{l}231 \\
548 \\
245\end{array}$ & $\begin{array}{r}8 \cdot 5 \\
19 \cdot 1 \\
9 \cdot 1\end{array}$ & $\begin{array}{r}5 \cdot 4 \\
12 \cdot 8 \\
5 \cdot 4\end{array}$ & $\begin{array}{l}21 \\
28 \\
25\end{array}$ & $\begin{array}{l}32 \\
33 \\
31\end{array}$ & $\begin{array}{l}11 \\
32 \\
42\end{array}$ & $\begin{array}{r}0 \\
7 \\
29\end{array}$ & $\begin{array}{r}8 \\
12 \\
10\end{array}$ \\
\hline $3\left\{\begin{array}{l}\text { Rest } \\
\text { Exercise } \\
\text { Histamine }\end{array}\right.$ & $\begin{array}{l}97.9 \\
90 \cdot 8 \\
91 \cdot 0\end{array}$ & $\begin{array}{l}17.7 \\
18 \cdot 4 \\
18 \cdot 1\end{array}$ & $\begin{array}{l}44 \\
84 \\
38\end{array}$ & $\begin{array}{l}232 \\
553 \\
235\end{array}$ & $\begin{array}{r}7 \cdot 9 \\
19 \cdot 3 \\
9 \cdot 6\end{array}$ & $\begin{array}{r}4 \cdot 4 \\
11 \cdot 4 \\
4 \cdot 7\end{array}$ & $\begin{array}{l}20 \\
24 \\
22\end{array}$ & $\begin{array}{l}34 \\
34 \\
33\end{array}$ & $\begin{array}{r}7 \\
46 \\
47\end{array}$ & $\begin{array}{r}1 \\
16 \\
33\end{array}$ & $\begin{array}{l}12 \\
11 \\
10\end{array}$ \\
\hline $4\left\{\begin{array}{l}\text { Rest } \\
\text { Exercise } \\
\text { Rest II } \\
\text { Histamine }\end{array}\right.$ & $\begin{array}{l}98 \cdot 4 \\
90 \cdot 1 \\
95 \cdot 4 \\
89 \cdot 6\end{array}$ & $\begin{array}{l}17 \cdot 4 \\
18 \cdot 2 \\
17 \cdot 5 \\
17 \cdot 7\end{array}$ & $\begin{array}{l}43 \\
97 \\
47 \\
30\end{array}$ & $\begin{array}{l}199 \\
639 \\
224 \\
222\end{array}$ & $\begin{array}{r}6 \cdot 2 \\
19 \cdot 7 \\
7 \cdot 0 \\
7 \cdot 5\end{array}$ & $\begin{array}{r}3 \cdot 1 \\
13 \cdot 0 \\
3 \cdot 6 \\
3.9\end{array}$ & $\begin{array}{l}20 \\
35 \\
23 \\
22\end{array}$ & $\begin{array}{l}42 \\
37 \\
40 \\
38\end{array}$ & $\begin{array}{l}-3 \\
48 \\
17 \\
43\end{array}$ & $\begin{array}{r}0 \\
15 \\
48\end{array}$ & $\begin{array}{l}7 \\
8 \\
6 \\
8\end{array}$ \\
\hline $5\left\{\begin{array}{l}\text { Rest } \\
\text { Exercise } \\
\text { Histamine }\end{array}\right.$ & $\begin{array}{l}98 \cdot 5 \\
95 \cdot 9 \\
88 \cdot 1\end{array}$ & $\begin{array}{l}16 \cdot 8 \\
17 \cdot 0 \\
16 \cdot 3\end{array}$ & $\begin{array}{l}41 \\
73 \\
37\end{array}$ & $\begin{array}{l}216 \\
657 \\
220\end{array}$ & $\begin{array}{r}5 \cdot 8 \\
18 \cdot 2 \\
6 \cdot 2\end{array}$ & $\begin{array}{r}3 \cdot 7 \\
14 \cdot 6 \\
4 \cdot 1\end{array}$ & $\begin{array}{l}18 \\
22 \\
18\end{array}$ & $\begin{array}{l}37 \\
36 \\
33\end{array}$ & $\begin{array}{r}0 \\
23 \\
48\end{array}$ & $\begin{array}{r}0 \\
5 \\
42\end{array}$ & $\begin{array}{r}6 \\
12 \\
7\end{array}$ \\
\hline $6\left\{\begin{array}{l}\text { Rest } \\
\text { Exercise } \\
\text { Histamine }\end{array}\right.$ & $\begin{array}{l}93 \cdot 7 \\
94 \cdot 2 \\
79 \cdot 4\end{array}$ & $\begin{array}{l}15 \cdot 9 \\
16 \cdot 7 \\
16 \cdot 9\end{array}$ & $\begin{array}{r}49 \\
109 \\
35\end{array}$ & $\begin{array}{l}237 \\
773 \\
290\end{array}$ & $\begin{array}{r}7 \cdot 5 \\
24 \cdot 4 \\
11 \cdot 8\end{array}$ & $\begin{array}{r}4 \cdot 3 \\
17 \cdot 6 \\
6 \cdot 3\end{array}$ & $\begin{array}{l}16 \\
26 \\
18\end{array}$ & $\begin{array}{l}41 \\
36 \\
34\end{array}$ & $\begin{array}{l}24 \\
34 \\
61\end{array}$ & $\begin{array}{r}14 \\
6 \\
90\end{array}$ & $\begin{array}{r}4 \\
17 \\
20\end{array}$ \\
\hline $7\left\{\begin{array}{l}\text { Rest } \\
\text { Exercise } \\
\text { Histamine }\end{array}\right.$ & $\begin{array}{l}97 \cdot 1 \\
94 \cdot 5 \\
94 \cdot 0\end{array}$ & $\begin{array}{l}16 \cdot 7 \\
17 \cdot 8 \\
16 \cdot 3\end{array}$ & $\begin{array}{r}61 \\
122 \\
53\end{array}$ & $\begin{array}{l}170 \\
531 \\
193\end{array}$ & $\begin{array}{r}5 \cdot 4 \\
13 \cdot 8 \\
6 \cdot 3\end{array}$ & $\begin{array}{l}2 \cdot 8 \\
9 \cdot 4 \\
3 \cdot 5\end{array}$ & $\begin{array}{l}24 \\
32 \\
26\end{array}$ & $\begin{array}{l}42 \\
38 \\
38\end{array}$ & $\begin{array}{l}14 \\
34 \\
34\end{array}$ & $\begin{array}{r}3 \\
5 \\
13\end{array}$ & $\begin{array}{r}2 \\
15 \\
7\end{array}$ \\
\hline $8\left\{\begin{array}{l}\text { Rest } \\
\text { Exercise } \\
\text { Histamine }\end{array}\right.$ & $\begin{array}{l}100 \\
93 \cdot 2 \\
85 \cdot 7\end{array}$ & $\begin{array}{l}17 \cdot 3 \\
18 \cdot 8 \\
17 \cdot 5\end{array}$ & $\begin{array}{r}83 \\
143 \\
53\end{array}$ & $\begin{array}{l}198 \\
553 \\
207\end{array}$ & $\begin{array}{r}5 \cdot 8 \\
19 \cdot 5 \\
7 \cdot 4\end{array}$ & $\begin{array}{r}3.9 \\
14.0 \\
4.0\end{array}$ & $\begin{array}{l}17 \\
36 \\
23\end{array}$ & $\begin{array}{l}36 \\
32 \\
36\end{array}$ & $\begin{array}{r}6 \\
46 \\
51\end{array}$ & $\begin{array}{r}0 \\
6 \\
41\end{array}$ & $\begin{array}{r}5 \\
18 \\
9\end{array}$ \\
\hline
\end{tabular}

$\mathrm{SaO}_{2}=$ Arterial oxygen saturation.

$\mathrm{O}_{2}$-cap. $=$ Oxygen capacity.

(A-v) $\mathrm{O}_{2}=$ Arteriovenous oxygen difference.

VO $_{2}=$ Oxygen consumption (ml./min. STPD).

$\dot{\mathrm{V}}_{\mathrm{E}}=$ Total ventilation (1./min. BTPS).

$\dot{\mathrm{V}}_{\mathrm{A}}=$ Alveolar ventilation (1./min. BTPS).
$\mathbf{R F}=$ Respiratory frequency.

(A-a) $\mathrm{O}_{2}=$ Alveolo-arterial $\mathrm{O}_{2}$ tension difference.

$\Delta \mathrm{p}=$ Respiratory pressure variations in the "PCV" pressure.

$\mathrm{Qs} / \mathrm{Qt}=$ Venous admixture as percentage of cardiac output.

$\mathrm{PaCO}_{2}=$ Arterial $\mathrm{CO}_{2}$ tension.

sure that pulse rates and intravascular pressures were restored to resting values before the infusion of histamine. Spirometry was performed with a modified Bernstein spirometer (Grimby and Söderholm, 1963).

Eight patients were referred to the laboratory for the assessment of cardiopulmonary function. Their subjective symptoms were of such a degree that the question of surgical treatment had been raised. So far, 6 of the patients have been operated upon, and the pre-operative diagnosis was verified.

Some information about the patients is to be found in Table I. The spirometric analyses show a moderate decrease in vital capacity without evidence for bronchial obstruction.

\section{RESULTS}

The results in each patient at rest, during exercise, and during histamine infusions are shown in Tables II and III. The average values at rest and the mean changes induced by the exercise and the infusion of histamine are shown in Tables IV and V.

At rest, all patients except No. 5 had signs indicative of mitral stenosis, e.g. raised mean pres- 
TABLE IV

Summary of Hemodynamic Changes

Mean Values ( \pm S.E.M.) at Rest and the Mean Individual Changes ( \pm S.E.M.) from the Values at Rest aRe GIVEN

\begin{tabular}{|c|c|c|c|c|c|c|c|c|}
\hline & \multicolumn{2}{|c|}{$\begin{array}{l}\text { Mean pressures } \\
(\mathrm{mm} . \mathrm{Hg})\end{array}$} & \multirow[b]{2}{*}{ PCV } & \multirow[b]{2}{*}{ SVR } & \multirow[b]{2}{*}{ PVR } & \multirow[b]{2}{*}{$\mathrm{CO}$} & \multirow[b]{2}{*}{ HR } & \multirow[b]{2}{*}{ SV } \\
\hline & $\begin{array}{c}\text { Brachial } \\
\text { artery }\end{array}$ & $\begin{array}{l}\text { Pulmonary } \\
\text { artery }\end{array}$ & & & & & & \\
\hline $\begin{array}{l}\text { Mean value at } \\
\text { rest } \pm \text { S.E.M. } \\
\text { Mean change }\end{array}$ & $112 \pm 7$ & $32 \pm 2 \cdot 6$ & $21 \pm 2 \cdot 0$ & $27 \pm 4 \cdot 5$ & $2 \cdot 8 \pm 0 \cdot 57$ & $4 \cdot 6 \pm 0 \cdot 47$ & $73 \pm 5 \cdot 0$ & $64 \pm 5 \cdot 5$ \\
\hline $\begin{array}{l}\text { during exer- } \\
\text { cise } \pm \text { S.E.M. } \\
\text { Mean change }\end{array}$ & $+8 \pm 5$ & $+26 \pm 2 \cdot 0 \ddagger$ & $+16 \pm 1 \cdot 1 \ddagger$ & $-8 \pm 1 \cdot 8 \dagger$ & $+0.9 \pm 0.33^{*}$ & $+2 \cdot 1 \pm 0.31 \ddagger$ & $+42 \pm 7 \cdot 8 \dagger$ & $-3 \pm 3 \cdot 7$ \\
\hline mine \pm S.E.M. & $-18 \pm 7 *$ & $+4 \pm 2 \cdot 3$ & $+7 \pm 2 \cdot 9^{*}$ & $-10 \pm 1 \cdot 4_{+}^{+}$ & $-1 \cdot 3 \pm 0.43^{*}$ & $+1.9 \pm 0.39 \dagger$ & $+19 \pm 6 \cdot 3^{*}$ & $+8 \pm 4 \cdot 1$ \\
\hline
\end{tabular}

For explanations, see Table II.

$*=\mathrm{p}$ value for difference from resting value $<0.05$.

$\dagger=p$ value for difference from resting value $<0.01$.

$\ddagger=p$ value for difference from resting value $<0.001$.

TABLE V

SUMMARY OF RESPIRATORY OBSERVATIONS

Mean Values ( \pm S.E.M.) at Rest are given and the Mean Individual Change ( \pm S.E.M.) during HISTAMINE AND EXERCISE

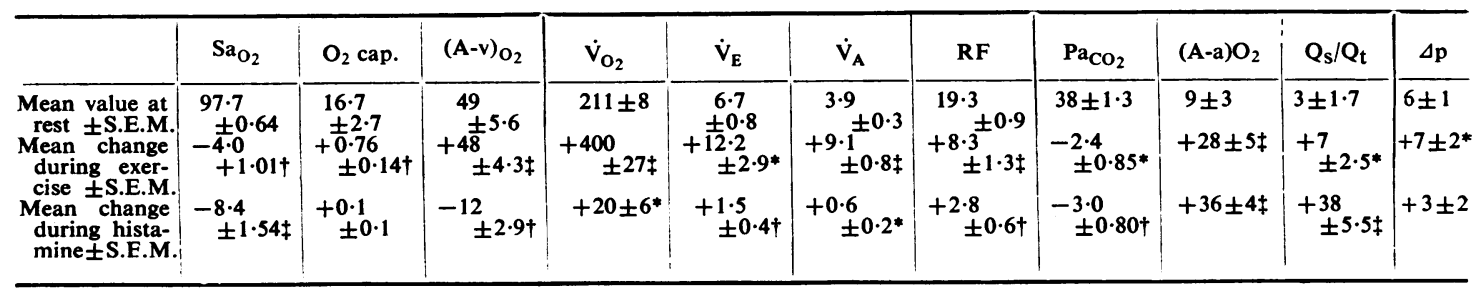

For explanations, see Tables III and IV.

sures in the pulmonary artery and the PCV position. The cardiac output and the arteriovenous difference in $\mathrm{O}_{2}$ content was abnormal in 2 patients, but fairly normal in the others. In 4 the calculated pulmonary vascular resistance was high. In all patients the arterial oxygen saturation was essentially normal and the arterial $\mathrm{PCO}_{2}$ was normal or low.

The exercise performed by the patients caused a threefold increase in the oxygen consumption. The cardiac output increased by about 50 per cent only. The arteriovenous $\mathrm{O}_{2}$ difference thus increased to very high values in some cases, indicating an insufficient circulatory adaptation to the exercise. The stroke volume did not change consistently. The PCV pressure rose to high levels in all cases. In 6 of the 8 patients the pulmonary arterial pressure increased out of proportion to the PCV pressure and the cardiac output. The pulmonary vascular resistance in these patients thus increased during exercise. The average increase in pulmonary vascular resistance for the whole group was significant at the 5 per cent level.

During histamine there was an increase in the pulse rate and a fall in brachial arterial pressure. The cardiac output increased in all patients: the vascular resistance in the larger circulation thus decreased. The arteriovenous $\mathrm{O}_{2}$ difference was reduced towards the normal level. The stroke volume increased slightly during histamine, but the average increase was not significant. In 4 of the 5 cases with sinus rhythm histamine increased the stroke volume by $14-19 \mathrm{ml}$,, i.e. by about 25 per cent. 
The increased pulmonary blood flow during histamine took place with a smaller pressure difference between the pulmonary artery and the left atrium, the latter as judged from the PCV pressure. The calculated pulmonary vascular resistance was thus substantially reduced and the mean value for all patients was normal during histamine infusion. The reaction to histamine is thus different from the reaction to physical effort, where the increased cardiac output occurred with a significant increase in resistance to blood flow through the lungs. The systemic vascular resistance, on the other hand, decreased during both exercise and histamine infusion.

Another striking change during histamine infusion was a decrease in arterial $\mathrm{O}_{2}$ saturation, averaging 8.4 per cent. During exercise the $\mathrm{O}_{2}$ saturation decreased by 4 per cent, on the average. The decrease in $\mathrm{O}_{2}$ saturation was parallel with the fall in pulmonary vascular resistance. The decrease in $\mathrm{O}_{2}$ saturation during histamine is not likely to have been caused by hypoventilation since the $\mathrm{CO}_{2}$ partial pressure decreased and the alveolar ventilation increased.

The calculated alveolo-arterial difference in $\mathrm{O}_{2}$ tension increased to high values both during histamine infusion and exercise: the calculated venous admixture increased to very high values during histamine infusion.

\section{Discussion}

The hæmodynamic and respiratory conditions at rest and during physical exercise in these patients are believed to be typical for a group of patients with mitral stenosis, causing moderate or moderately severe disablement. The effects of histamine that seem to be of interest and warrant discussion are (1) the increase in cardiac output (and sometimes also stroke volume), (2) the decrease in pulmonary vascular resistance, and (3) the decrease in arterial $\mathrm{O}_{2}$ saturation.

The increase in cardiac output during the infusion of histamine was caused mainly by an increase in the pulse rate. However, in some cases with sinus rhythm the stroke volume also increased. The mechanism behind the increased cardiac performance during histamine infusion is not known. We have recently observed (Lindell et al., 1963) that histamine can increase the cardiac output, the stroke volume, and the stroke work in cases with chronic constrictive pericarditis. Evidence was obtained that this action of histamine must to some extent be caused by a direct stimulating effect of histamine on myocardial contractility. An increase in the stroke volume also occurs if histamine is given to normal subjects (Bjure et al., 1962). In the group of patients with mitral disease presently discussed the effect of histamine on stroke volume was not statistically significant. This is in keeping with the view that the stroke volume in mitral stenosis is kept low mainly by mechanical factors, i.e. the size of the mitral ostium. Further observations are needed to establish whether histamine increases the stroke volume more in patients with mitral stenosis with sinus rhythm than in patients with atrial fibrillation.

The increase in cardiac output during the infusion of histamine was accompanied by a rise in the PCV pressure, particularly so in the patients with atrial fibrillation. During physical exercise, which increased the cardiac output to about the same values as during histamine, the PCV pressure was much higher than during histamine. This is likely to be due to impeded ventricular filling at the higher heart rate during exercise. In normal subjects histamine increased the cardiac output without an increase in the PCV pressure (Bjure et al., 1962).

Whatever the mechanism of its action, histamine provides a means for increasing the cardiac output in mitral disease, and it is suggested that histamine could be used, instead of physical exercise, under conditions that make physical exercise difficult or hazardous for the patient, e.g. certain types of left heart catheterization. In such examinations the mode of action of histamine on the stroke volume could be analysed by simultaneous pressure measurements in the left atrium and ventricle. The effect of histamine on the stroke work of the left ventricle could not be estimated from the presently reported experiments, in which inter alia the left ventricular diastolic pressure was not known.

It seems very likely that the reduced pulmonary vascular resistance caused by histamine is a 
result of dilatation of the pulmonary vessels. A pronounced reduction of pulmonary vascular resistance after histamine indicates that functional changes, e.g. active vasoconstriction, were in part responsible for the pulmonary hypertension. The mechanism behind a constriction of pulmonary vessels in patients with mitral stenosis is not known. Hypoxia in poorly ventilated parts of the lung might be responsible (Söderholm and Werkö, 1959), but other factors also may be of importance (Wood et al., 1957; Söderholm, Werkö, and Widimský, 1962). It seems that histamine may, in addition to acetylcholine, be used as a tool to differentiate between functional and anatomical causes of increased pulmonary vascular resistance. With acetylcholine infusion, in a proper dose, a selective effect on the pulmonary vessels may be obtained (Söderholm and Werkö, 1959). On the other hand, failure to respond to acetylcholine does not necessarily signify an anatomical cause for increased pulmonary resistance, since inadequate dosage may be responsible. Furthermore, acetylcholine may be dangerous in patients with congenital heart disease involving right-to-left shunting of blood. Histamine is not inactivated during the passage through the lungs (Arnoldsson et al., 1962), and the presence of a shunt would thus make little difference. With histamine, it is easy to know, by following the pulse rate and the colour of the skin, that an effective dose is being given. The generalized circulatory effects of histamine may, however, be disadvantageous and make the results more difficult to interpret.

The decrease in arterial $\mathrm{O}_{2}$ saturation was a conspicuous effect of histamine. In 8 normal subjects histamine decreased the arterial $\mathrm{O}_{2}$ saturation only slightly, the mean decrease being 1.3 per cent. This figure should be compared with the average decrease of 8.4 per cent in the present group of patients with mitral stenosis and the mean decrease of 4.2 per cent in 4 cases of constrictive pericarditis (Lindell et al., 1963). The effect of histamine on the $\mathrm{O}_{2}$ saturation thus seems to be more pronounced in patients with heart disease. This finding was in fact made many years ago by Tang (1932), Klein and Nonnenbruch (1933), and Heymer and Grosse-Brockhoff (1934) and others, and it was proposed that histamine might be used to disclose a 'latent' impairment of pulmonary function in heart disease.

Apparently the same difference between normal subjects and patients with heart disease prevails with regard to the response of the arterial $\mathrm{O}_{2}$ saturation to acetylcholine. Thus Söderholm and Werkö (1959) found an average decrease of 6 per cent $\mathrm{O}_{2}$ saturation on infusing acetylcholine to 10 patients with mitral valve disease, whereas Bjure et al. (1962) found no certain effect of similar or larger doses of acetylcholine in healthy subjects.

The cause of the decreased arterial $\mathrm{O}_{2}$ saturation after giving histamine to patients with heart disease is not definitely known. Impaired pulmonary ventilation due to, for example, bronchoconstriction can probably be excluded, since the arterial $\mathrm{CO}_{2}$ tension decreased slightly and the alveolar ventilation increased. The slight increase in respiratory pressure variations during histamine could be indicative of bronchial obstruction, but measurement of the rate of nitrogen elimination during oxygen breathing gave no evidence for a bronchoconstrictor action of histamine, as used in the present study (unpublished observations). The slightly increased respiratory pressure variations were thus probably caused by the increased ventilation and/or increased vascular engorgement of the lungs during histamine infusion. The pulmonary diffusion capacity for carbon monoxide was not decreased after histamine given by vein (Bjure and Söderholm, unpublished observations).

The most likely explanation for the decrease in arterial $\mathrm{O}_{2}$ saturation is that histamine opened up vessels perfusing poorly ventilated parts of the lung. These vessels presumably were constricted in response to local hypoxia, and, in this way, a normal arterial $\mathrm{O}_{2}$ saturation was maintained. On infusion of histamine (or acetylcholine) this compensated disturbance in the ventilation-perfusion relation is disclosed, and the pulmonary vascular resistance is decreased towards the normal level. Further support for the view that histamine opens up vessels to poorly ventilated parts of the lung was sought by calculating the alveolo-arterial $\mathrm{O}_{2}$ tension difference and the percentage venous admixture to arterial blood. The calculations of both these parameters are based on some assumptions that may not be fully accurate during histamine infusion. Thus, in the calculation of the 
venous admixture it was assumed that the $\mathrm{O}_{2}$ saturation in the "venous" end of the pulmonary capillaries was 98 per cent. Nevertheless, the increases during histamine of the venous admixture and the alveolo-arterial $\mathrm{O}_{2}$ tension difference were so considerable that they are regarded as additional evidence that histamine causes a renewed perfusion of underventilated parts of the lungs.

\section{SUMMARY}

Eight patients with mitral stenosis were subjected to right heart catheterization, and observations were made at rest, during exercise, and during an intravenous infusion of histamine.

At rest and during exercise the patients had hæmodynamic and respiratory changes characteristic of mitral stenosis. Histamine infusion caused, among other things, an increase in the cardiac output, a decrease of the pulmonary vascular resistance, and a lowering of arterial $\mathrm{O}_{2}$ saturation.

The mechanisms of action of histamine on the circulation and respiration in mitral stenosis are discussed.

The expert assistance of Nurse A-G. Kindström is gratefully acknowledged.

\section{REFERENCES}

Arnoldsson, H., Helander, C.-G., Helander, E., Lindell, S.-E., Lindholm, B., Olsson, O., Roos, B.-E., Svanborg, A., Söderholm, B., and Westling, H. (1962). Elimination of C14-histamine from the blood in man. Scand. $J$ clin. Lab. Invest., 14, 241.

Bernéus, B., Carlsten, A., Holmgren, A., and Seldinger, S. I. (1954). Percutaneous catheterization of peripheral arteries as a method for blood sampling. Scand. J. clin. Lab. Invest., 6, 217.

Bjure, J., Helander, E., Lindell, S. E., Söderholm, B., and Westling, H. (1962). Effect of acetylcholine and histamine on the pulmonary ventilation and perfusion in normal man. XXII International Congress of Physiological Sciences, Leiden.

Carlsten, A., and Söderholm, B. (1960). Carbon dioxide tension and pH of lymph and arterial blood in anæsthetized dogs. Acta physiol. scand., 48, 29.

Grimby, G., and Söderholm, B. (1963). Spirometric studies in normal subjects. III. Static lung volumes and maximum voluntary ventilation in adults with a note on physical fitness. Acta med. scand., 173, 199.

Heymer, A., and Grosse-Brockhoff, F. (1934). Lungenfunktionsprüfung durch Histamin. Dtsch. Arch. klin. Med., 176, 651 .

Klein, O., and Nonnenbruch, W. (1933). Über Funktionsprüfung der Lunge durch Histamin. Z. Klin. Med., 125, 29.

Lindell, S.-E., Svanborg, A., Söderholm, B., and Westling, H. (1963). Hæmodynamic changes in chronic constrictive pericarditis during exercise and histamine infusion. Brit. Heart J., 25, 35.

Rahn, H., and Fenn, W. O. (1955). A graphical analysis of the respiratory gas exchange. Amer. Physiol. Soc., Washington.

Söderholm, B. (1957). The hæmodynamics of the lesser circulation in pulmonary tuberculosis. Scand. J. clin. Lab. Invest., 9, suppl. 26.

21,1 .

, and Widimský, J. (1962). The effect of acetylcholine on pulmonary circulation and gas exchange in cases of mitral stenosis. Acta med. scand., 172, 95 .

Tang, C. (1932). Einfluss des Histamins auf die arterielle Sauerstoffbindungskurve und auf den arteriellen Sauerstoffdruck (Ein Beitrag zur Histaminwirkung auf die Lungengefässe). Naunyn-Schmiedeberg's Arch. exp. Path. Pharmak., 168, 274.

Wood, P., Besterman, E. M., Towers, M. K., and Mcllroy, M. B. (1957). The effect of acetylcholine on pulmonary vascular resistance and left atrial pressure in mitral stenosis. Brit. Heart J., 19, 279. 